\title{
Living Rights: Reflections from Women's Movements about Gender and Rights in Practice
}

\section{Cindy Clark, Molly Reilly and Joanna Wheeler*}

\section{Introduction}

Since the UN Universal Declaration of Human Rights over 50 years ago, there has been a proliferation of international conventions on rights. Currently, the international legal framework encompasses an astounding variety, stretching from women's rights to rights of indigenous peoples to knowledge rights. But despite the burgeoning number of formal rights at the international and national level, substantive rights in practice remain elusive for most. At the same time, there is increasing evidence that innovative approaches that integrate rights into development practice can have real impact on entrenched problems of poverty and injustice. Using rights in development to address marginalisation and exclusion requires new thinking about understanding how rights can be made substantive.

A gendered approach to rights fundamentally shifts the way that rights are understood. It requires understanding rights not merely as legal entitlements, but also as a political tool in social change strategies. Combining gender and rights provides a way to examine values, behaviours, assumptions, policies and programme decisions to determine how they play a role in excluding or discriminating against some people and favouring others; looking at different kinds of subordination, based on gender as well as class, ethnicity, caste, age and other factors. Essentially, a gendered analysis of rights reminds us that rights do not apply to some "neutral" individual, but rather that the application and enjoyment of rights differs according to a person's power and position in society and the roles that are attributed to her or him.

Women's movements have been at the forefront of efforts to make rights real and have produced tremendous contributions to knowledge about how to use rights to combat marginalisation and exclusion. First, the concepts and tools associated with gender analysis help make the link between rights and power in both public and private spheres. Gender analysis clarifies the role of power relations in mediating the experience of rights, highlighting how rights cut across the realms of people's experience and identity, from public political action to intimate and personal relations. Feminist thinkers have expanded the notion of rights, as operating at different levels, from economic, to social, to political, to personal dimensions, noting that an absence of rights at one level jeopardises the fulfilment of rights at all levels (Sen 2003). It is the experience of rights across these levels and in different realms that actually gives them meaning in practice. These experiences underscore how different categories of rights (often separated for geopolitical reasons) are interrelated (see Cornwall and Nyamu-Musembi, this issue). For example, much of the current good governance agenda advanced by the World Bank and particularly US Agency for International Development promotes certain political and civil rights. But while these rights are important, the absence, in daily experiences, of other rights can undermine these. For example, promoting political and civil rights such as voting is important, but if women and men can vote, but face domestic violence in their homes, this erodes the meaning of formal political rights. A gendered analysis also helps show how the definition and framing of rights is often the product of struggles in particular contexts and legal frameworks. And in the process of challenging the meaning of rights, rights are also used strategically by women's movements and others to advance both practical and structural goals. 
Drawing on the experiences of the women's human rights movement over the last three decades, this article will explore some of the main contributions that a gendered approach can make to understanding how rights can be used in practice to address exclusion and marginalisation.

\section{Power affects all human interaction}

One of the most important contributions of gender to understanding rights is to foreground the role of power relations in daily interactions. Feminist thinkers and activists made clear that gender is not just about biological difference between men and women or girls and boys. Gender roles and behaviours are socially constructed, vary according to culture and can change over time. Through gender and other discriminatory social values assigned on the basis of factors such as race, class, ethnicity, disability and the like, dominant groups are able to create and reinforce relations of power and inequality and also to minimise and submerge the conflicts inherent in unequal power relations. A gendered approach to rights is fundamentally about understanding relations of power.

As Hughes et al., Miller et al. (page 31) and Pereira Júnior et al. point out in this IDS Bulletin, power is a critical factor in social change. Yet power relations are rarely taken into account in a thoughtful and systematic manner in the planning of development programmes or social change efforts. Gender theory and practice sheds light on how power is experienced in different areas of life, and provides concepts that can assist in the development of holistic strategies that address the causes of powerlessness and inequality. For example, the public realm of power refers to the visible face of power as it affects women and men in their jobs, public life, legal rights, etc. The private realm of power refers to relationships and roles in families, among friends, sexual partnerships, etc. The intimate realm of power has to do with one's sense of self, personal confidence, psychology and relationship to body and health. The experience of power may be contradictory in these different realms of life. Acknowledging these layers and contradictions can be helpful in understanding the tensions generated by empowerment for many people. Change strategies that focus solely on the public realm may overlook critical challenges facing people, especially women, when they return to their homes and families.
The challenge of HIV/AIDS prevention illustrates the need to integrate power analysis into development and social change strategies. Many women and men around the world who appear educated and empowered in their public lives fail to take measures to protect themselves against the disease despite the knowledge and resources to do so. Similarly, many women and girls lack the power to negotiate with their families and/or sexual partners about marriage and sexual relations. There is a growing consensus that tackling the global HIV/AIDS pandemic demands altering unequal relations so as to decrease vulnerability, but strategies that fail to address power dynamics in the private and intimate realms will have limited impact.

\subsection{Power and identity}

Each individual's experience of power and powerlessness is fluid, relational and differs based on gender, race, class, age, etc. What determines who has more power and who has less power in society and in development processes? Physical traits and social circumstances that are inherited at birth often determine an individual's opportunities, choices and even sense of self. This happens not because these characteristics are inborn, but rather because of negative value judgements attributed to them. People then often justify prejudice as "natural", when it is really the social meaning given to attributes like gender, class, ethnicity, age, location, or sexual orientation that defines inequality.

Every individual has multiple identities that may afford different levels of advantage, depending on the situation. In India, categories of identity including caste, religion and gender combine in different ways to perpetuate certain forms of exclusion. And the interaction between different categories of identity and legal formulations of rights can undermine the ability of women or other subordinate groups to claim their rights:

... Shah Bano [is] a Muslim woman who had applied for the right to maintenance from her exhusband under criminal law proceedings (Mukhopadhay 1998; Menon 1998). This was a right which had been quietly accessed by Muslim women prior to the case. However the decision of the Supreme Court to publicly uphold this right ... made the case a matter of intense public controversy. For many Muslims, the Court's decision appeared to violate Shari'a law and 
undermine the only legal recognition of their separate identity they had been granted as Indian citizens. For many feminists, it was a vindication of a woman's right as a citizen in a democratic state to have a uniform civil code. For Hindu militants, it was a judgement about the backwardness of women's position in Islam ... For Shah Bano herself, the decision appeared to pose the different aspects of her identity - as a woman, as a Muslim, and as an Indian - as standing in contradiction to each other. She publicly rescinded her right to maintenance and declared her loyalty as a Muslim. (Kabeer 2002)

\subsection{Changing the balance of power}

Understanding the centrality of power relations to the experience of rights can inform strategic choices about how to achieve rights. Gender theory and practice has produced some analytical concepts which clarify the power imbalances that must be taken into account in efforts to uphold rights and counter exclusion. One key concept is the distinction between practical and strategic needs and interests, which is intended to keep the focus on equity and empowerment. Practical needs and interests relate to immediate necessities like water or health care. Strategic needs and interests, on the other hand, are those that relate to power, status and control. Programmes that aim to address strategic needs seek to transform existing unequal power relations. While the distinction between practical needs and strategic interests can be helpful in identifying short-term and long-term priorities, it is often interpreted in ways that give greater legitimacy to strategic interests than to practical needs. In processes aimed at countering marginalisation and exclusion, however, it is not always helpful to view the choice between practical and strategic interests as an "either/or" case. Rather, pressing practical needs can be an important entry point for women, the poor, or other marginalised groups to become engaged in solving their problems in a tangible way and, over the longterm, challenging inequitable power relations. For example, the right to a livelihood could be reinterpreted to mean land-holding patterns must be changed to give women control over land, so that they can have the basis for sustainable livelihoods. In addition to the process of framing the meaning of rights, a gendered analysis shows how rights can be used strategically to achieve both practical and more far-reaching structural goals.
Gender theory also draws a distinction between the use or access to material, political or social resources, such as farm land or decision-making processes on the one hand and the capacity to influence, shape or control those resources on the other. This distinction helps to clarify the different power men and women are given over important social goods. Access is the opportunity to make use of a resource. Control, on the other hand, implies the power to decide how a certain resource is used and who is to be given access to it. For example, women often have access to land, but not control over how it is used (e.g. for cash crops or subsistence farming) or whether it is sold.

\subsection{The experience of rights}

There is sometimes a tendency to think about rights as existing only in the legal or institutional context. Lived human experience, however, suggests that rights exist in every sphere of life: home, school, street, workplace, market, etc. In fact, deep-rooted social and cultural beliefs and biases are usually more significant than laws in preventing the poor, women and other marginalised groups from making choices and exercising rights. Thus, addressing social and cultural bias and discrimination, rather than merely seeking changes in law and policy, is a critical aspect of strategies aimed at building a society that respects, upholds and fulfils every person's rights.

Recent research on gender and citizenship in Brazil points to the importance of how rights and citizenship are experienced in daily life. Many men and women living in Rio de Janeiro's favelas (illegal squatter settlements) identified dignity in everyday spaces: in homes, bus stops, schools and markets, as a key aspect of substantive citizenship (Wheeler 2003). In contrast, the formal rights set out in the progressive 1988 constitution in Brazil, at the end of two decades of military dictatorship, had little purchase on the lives of marginalised men and women. As one woman who lives in a Rio de Janeiro housing project says: 'Dignity is everything for a citizen - and we have no dignity. We are treated like cattle in the clinics, on the buses and in the shops. Only in rich neighbourhoods are people treated with dignity'.

\section{Reconceptualising rights}

There is sometimes a tendency to view human rights as set in stone or "handed down from on high", rather than as the product of centuries of struggle 
Figure 1: Key Elements of "Making Rights Real” - A Framework

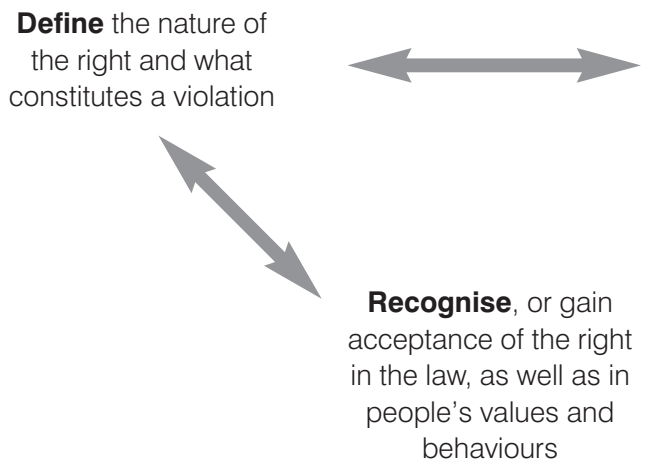

Enforce the right, assuring its enjoyment by all, holding violators accountable

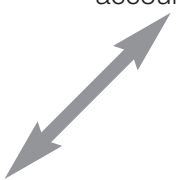

to translate human needs and interests into enforceable commitments. This view offers little scope for bringing new voices into the rights discourse. Rejecting a static understanding of rights, women's rights activists reconceptualised rights as an evolving, dynamic framework that is in fact strengthened by the inclusion of new, previously excluded, voices in an ongoing project of refinement and redefinition. Along the way, women's movements reinterpreted human rights that were not thought to apply to women in new ways, expanded the sphere of state responsibility and gained greater recognition and enforcement of women's rights. For example, rather than take the existing bundle of rights as an unchangeable given, women's rights activists over the past two decades have articulated and claimed "new" rights, such as the right to live free from domestic violence, that address areas of women's experience which were not previously understood or accepted as "human rights" violations. The dynamic view of rights helpfully emphasises the centrality of process in strategies that link rights with participation by excluded groups. Both the processes of giving meaning to rights and of using rights in practice are essential to understanding how rights can be made substantive. Figure 1 shows the framework (see Schuler 2004 and page 59, this issue) developed by women's rights activists as a tool for expanding the dynamic conception of rights and illustrates key elements of "making rights real" in people's lives.

\section{Claiming rights}

Building on a dynamic understanding of rights, women's rights activists constructed processes and approaches to claiming rights that begin with urgent practical problems and ultimately build a sense of empowerment and active citizenship. For marginalised groups including women, claiming rights is part of a process that includes building alternative forms of power, specifically, the power gained from defining collective demands, from researching and generating new knowledge, from building new relationships within civil society and with the state. The change process engages communities and individuals most affected by a problem in analysis, planning and action. Over time, the change is both individual (acquiring a new consciousness of one's situation) and collective: private and public.

In Chiapas, Mexico, indigenous women involved in the Zapatista movement have articulated a set of rights and vision for development that draws on their specific experiences of exclusion. They have worked to advance these rights in diverse political spaces, from local committee meetings to the national congress. Through the process of articulating their rights, the women's movement in Chiapas has also led to a sense of empowerment among those involved; a new and more promising sense of the possible. For example, some women have organised artisan cooperatives, where they work to ensure sustainable livelihoods and also advance their rights: 
The artisan organizations helped empower women by transforming individual and private problems into public and collective ones. The most important outcome has been that women are now acting collectively to find their own solutions and construct alternative forms of family, community and social relations. The artisan organizations offer hope that a different future is possible. (Cortez 2005)

As Luvia, an indigenous Zoque from the Sierra region said:

For me, the workshops are very important because we can express our opinions and come to agreements. We can think and take advantage of all the experiences of different women who come from different places and different regions. That is why such meetings are very important, because we can share experiences and ideas. It is important because we are learning about women's rights; about the rights and responsibilities that we have in the family, the society and in the church. (Cortez 2005)

In Bangladesh, Naripokkho, a leading women's NGO has mobilised to investigate how women experience their lack of rights. Specifically, Naripokkho seeks to move beyond the narrowly defined women-in-development agenda, which focuses on a specific technical agenda including maternal mortality and family planning. As Naripokkho began to explore women's rights in Bangladesh, an articulation of the links between the process of collective political action and priorities within women's rights came to the fore:

The right not to be discriminated against - that is, the right to non-discrimination - was then our starting point; the basis on which we demand equality and justice. Our experience of discrimination as women led us to demand fair treatment and respect for our dignity as human beings, and only thereafter to claim our rights and entitlements as citizens. It is only through the process of seeking redress for unfair treatment, for discrimination and in demanding changes in the law, in cultural behaviour and in demanding accountability of the state that we became aware of ourselves as citizens and as bearers of rights. (Huq 2005)

\section{A critical stance}

As the examples from Mexico and Bangladesh demonstrate, incorporating rights into development and social change initiatives does not imply an uncritical acceptance of the formal legal system, including the international human rights system. Many activists find international rights language unhelpful in their contexts. Many have critiqued the UN system for its lack of practical impact and inattention to critical economic and social rights, to say nothing of its failure to incorporate gender. Rather than an unquestioning acceptance of what currently exists, a rights-based approach requires a critical perspective on the rights framework and a vision of how it might respond more constructively to human struggles for dignity and fulfilment, combined with careful strategic choices about where it is possible to use existing legal and institutional structures, and where it is possible and necessary to challenge them.

In the North-West region of Nigeria, for example, Muslim women are organising for their rights. They are framing their claims not with reference to the constitution or international law, but through a broad social advocacy strategy, talking about the role and status of women within religious law and tradition (Toyo et al. 2004). Claiming universal rights is seen as risky and possibly counter-productive. Instead, a strategic choice was made to draw upon positive elements within the cultural and religious context, seeking to claim rights with reference to the emphasis on justice and fairness within Shari'a (ibid), rather than appealing to controversial international human rights conventions.

On the other hand, women's movements have drawn upon international legal frameworks strategically to enhance their claims, and have worked to re-frame the definition of rights in certain key instruments such as the Beijing Platform for Action and Convention on the Elimination of All Forms of Discrimination Against Women (CEDAW). However, many feminists argue that international conventions such as the Beijing Platform and CEDAW have also excluded some important perspectives on gender issues because of political pressures to set a common agenda.

\section{Conclusion}

The value of rights does not lie merely in the fact that they exist, in some abstract way, in international or national legal frameworks, or that people's lives 
will be improved by knowing about rights. Rather, the value of rights lies in how they can be used as a political tool in efforts to bring about social change. This article has drawn together some reflections about how a gendered analysis of rights can inform understandings of how rights can be used in practice. Drawing on examples from women's movements, a gender analysis of rights can teach us a lot about how rights are experienced, have meaning, and are mediated by power relations. In some circumstances, it adds power to a claim to

\section{Notes}

* This article is partly adapted from Lisa VeneKlasen with Valerie Miller, A New Weave of Power, People and Politics: The Action Guide for Advocacy and Citizen Participation (2002). Examples are drawn from recent research conducted as part of the Development Research Centre on Citizenship, Participation, and Accountability, which is a collaborative initiative working to help make rights and citizenship matter.

\section{References}

Cortez, C., 2005, 'Rights and Citizenship of Indigenous Women in Chiapas: A History of Struggles, Fears, and Hopes', in N. Kabeer (ed.), Inclusive Citizenship: Meanings and Expressions, London: Zed Books

Huq, S., 2005, 'Bodies as Sites of Struggle: Naripokkho and Women's Rights in Bangladesh', in N. Kabeer (ed.), Inclusive Citizenship: Meanings and Expressions, London: Zed Books

Kabeer, N., 2002, 'Citizenship and the boundaries of acknowledged community: identity, affiliation and exclusion', IDS Working Paper 171, Brighton: Institute of Development Studies

Menon, N., 1998, 'Women and Citizenship', in P. Chatterjee (ed.), Wages of Freedom: Fifty Years of the Indian Nation State, New Delhi: Oxford University Press: 261-66

Mukhopadyhay, M., 1998, Legally Dispossessed: Gender, Identity and the Process of Law, Calcutta: Stree Publications

Schuler, M., 2004, Women's Human Rights Step by Step: Strategy Workbook. Washington D.C.: Women, Law and Development International frame it in terms of a right, which may be accepted in principle but ignored in fact. Through taking action to solve problems, people gain confidence and consciousness of themselves as the subjects of rights. Recognising when and how to use rights in a social change strategy is an important part of a rights-based approach. But, perhaps the most significant accomplishment of the global movement is the new consciousness about rights that is reaching women everywhere.

Sen, G., 2003, 'Feminist Politics in a Fundamentalist World', in M. Mukhopadhyay (ed.), Governing for Equity: Gender, Citizenship and Governance, Amsterdam: Royal Tropical Institute (KIT)

Toyo, N. with Nweze, J.C.C., Agary, K., Agary, T.K., Abdu, H. and Jada, I.N., 'Linking rights and participation: Nigeria case study - exploring experiences from the Niger Delta to the North West region', Brighton: Institute of Development Studies, www.ids.ac.uk/particip/rights (accessed December 2004)

VeneKlasen, L. with Miller, V., 2002, A New Weave of Power, People and Politics: The Action Guide for Advocacy and Citizen Participation, Oklahoma: World Neighbors

Wheeler, J., 2003, 'New forms of citizenship: democracy, family and community in Rio de Janeiro, Brazil', Gender and Development, Vol 11 No 3 